Journal of Animal and Veterinary Advances 9 (20): 2578-2582, 2010

ISSN: $1680-5593$

(C) Medwell Journals, 2010

\title{
An Investigation on Some Haematological and Biochemical Parameters in Capoeta trutta (Heckel 1843) from Munzur River (Tunceli, Turkey)
}

\author{
${ }^{1}$ Durali Danabas, ${ }^{2}$ Nuran Cikcikoglu Yildirim, ${ }^{1}$ Azime Kucukgul Gulec \\ ${ }^{2}$ Numan Yildirim and ${ }^{3}$ Olcay Kaplan \\ ${ }^{1}$ Department of Aquaculture, Faculty of Fisheries, \\ Tunceli University, Tunceli, Turkey \\ ${ }^{2}$ Department of Environmental Engineering, \\ Faculty of Engineering, Tunceli University Tunceli, Turkey \\ ${ }^{3}$ Department of Food Engineering, Faculty of Engineering, \\ University of Tunceli, Tunceli, Turkey
}

\begin{abstract}
Fishes are largely used for the assessment of aquatic environment quality and are accepted as bioindicators of environmental pollution. This study evaluated haematological and biochemical responses of Capoeta trutta captured in Munzur River, Tunceli, Turkey. Blood and biochemical parameters (Sodium (Na), Potassium $(\mathrm{K})$, Calcium $(\mathrm{Ca})$, Phosphorus $(\mathrm{P})$, Chlorine $(\mathrm{Cl})$ and Iron $(\mathrm{Fe})$ ) were determined. The values of Red Blood Cell (RBC) Haemoglobin (Hb), Haemotocrit (Ht), Mean Corpuscular Volume (MCV), Mean Corpuscular Haemoglobin (MCH), Mean Corpuscular Haemoglobin Concentration (MCHC), Platelet Count (PLT), Mean Platelet Volume (MPV), Plateletcrit (PCT), Platelet Distribution Width (PDW) from examined haematological parameters were found as $0.67 \pm 0.0910^{12} \mathrm{~L}^{-1}, 13.5 \pm 0.90 \mathrm{~g} \mathrm{dL}^{-1}, 14.78 \pm 0.19 \%, 218.40 \pm 4.29 \mathrm{fL}, 194.75 \pm 15.36 \mathrm{pg}$, $108.52 \pm 1.09 \mathrm{~g} \mathrm{dL}^{-1}, 34.12 \pm 5.8910^{9} \mathrm{~L}^{-1}, 11.92 \pm 1.65 \mathrm{fL}, 0.061 \pm 0.01 \%$ and $19.77 \pm 1.71 \mathrm{fL}$, respectively. The values of $\mathrm{Fe}, \mathrm{Cl}, \mathrm{P}, \mathrm{Ca}, \mathrm{K}$ and $\mathrm{Na}$ from examined biochemical parameters were determined as $91.75 \pm 28.27 \mathrm{~g} \mathrm{dL}^{-1}$, $92.00 \pm 4.02 \mathrm{mmol} \mathrm{L}^{-1}, 13.20 \pm 1.26 \mathrm{mg} \mathrm{dL}^{-1}, 11.65 \pm 0.74 \mathrm{mmol} \mathrm{L}^{-1}, 1.30 \pm 0.21 \mathrm{mmol} \mathrm{L}^{-1}$ and $132.5 \pm 3.90 \mathrm{mg} \mathrm{dL}^{-1}$ respectively. Observation of blood parameters allows the most rapid detection of changes in fish after the exposure to xenobiotics. It can conclude that hematological and biochemical parameters could be ranked as possible biomarkers of pollution.
\end{abstract}

Key words: Haematology, biochemistry, Capoeta trutta, Munzur river, biochemical parameter, bioindicator

\section{INTRODUCTION}

Biomarkers are defined as a change in a biological response, ranging from molecular to cellular and from physiological responses to behavioral changes which can be related to the toxic exposure or to the toxic effects of environmental chemicals (Depledge et al., 1995). On the other hand, biomarkers are responses to environmental effects that occur at higher levels of the biological organization than suborganism and can be measured in the individual, population, community (primary production, distuption of the nutrient cycle) and ecosystem levels (Walker et al., 2001). Fish and crustaceans are largely used for the assessment of aquatic environment quality and are accepted as bioindicators of environmental pollution (Borkovic et al., 2008). The physiological stress is clearly reflected by blood patterns of the experimented fish. Studies have shown that when the water quality is affected by toxicants, any physiological changes will be reflected in the values of one or more of the hematological parameters (Van Vuren, 1986). Thus, water quality is one of the major factors, responsible for individual variations in fish hematology, since they live in close association with their environment and are sensitive to slight fluctuation that may occur within their internal milieu (Casillas and Smith, 1977). The use of hematological parameters as fish health indicators has been proposed by Hesser (1960). Hematology is used as an index of fish health status in a number of fish species to detect physiological changes following different stress conditions like exposure to pollutants, diseases, metals, hypoxia, etc. (Blaxhall, 1972; Duthie and Tort, 1985). Therefore, hematological techniques are the most common method to determine the sub-lethal effects of the pollutants (Larsson et al., 1985). Evaluation of the haemogram involves the determination of the $\mathrm{RBC}$, total white blood cell count (WBC), $\mathrm{Ht}, \mathrm{Hb}$, erythrocyte indices (MCV, MCH, MCHC), white blood cell differential count and the evaluation of stained peripheral blood films (Campbell, 2004). Mean cell hemoglobin

Corresponding Author: Nuran Cikcikoglu Yildirim, Department of Environmental Engineering, Faculty of Engineering, University of Tunceli, Tunceli, Turkey 
concentration measure was used to assess the amount of red cell swelling (decreased $\mathrm{MCHC}$ ) or shrinkage (increased MCHC) present (Milligan and Wood, 1982). The macro elements $\mathrm{Ca}$, Magnesium $(\mathrm{Mg}), \mathrm{Na}, \mathrm{K}$ and $\mathrm{P}$ are essential to human health (Przybyl and Koligot, 1997a).

Microelements such as Zinc ( $\mathrm{Zn}), \mathrm{Fe}$, Copper (Cu) and Manganese $(\mathrm{Mn})$ which occur in physiological concentrations, play key roles in living processes and either an excess or deficit can disturb biochemical functions in both humans and animals (Przybyl and Koligot, 1997b).

The Capoeta trutta used in the present study came from Munzur River. Capoeta trutta is grown commercially in this reservoir. The present study was designed to determine whether some hematological and biochemical parameters could be useful indicators of the aquatic pollution in Capoeta trutta.

\section{MATERIALS AND METHODS}

The experiment was organized on Aquaculture Department, Fisheries Faculty and Faculty of Engineering, Department of Environmental Engineering on Tunceli University (Tunceli, Turkey).
Locality: The localities were shown in Fig. 1. The fish was caught from river mouth of Munzur River with gill net ( $20 \mathrm{~m}$ length and $10 \mathrm{~cm}$ diameter) on 10 April 2010 .

Fish: In this study, wild fishes of Capoeta trutta (Heckel, 1843) were used for biomonitoring purpose. The fish $(n=5)$ was caught from their natural areas in Munzur River (Tunceli, Turkey). These fishes had been anaesthetized immediately $0.7 \mathrm{~g} \mathrm{~L}^{-1}$ benzocaine dissolved in ethyl alcohol (Sardella et al., 2004) and observed anesthesia of fish being deep sedation, losing of swimming actions and partial losing of equilibrium (Altun and Danabas, 2006).

Blood sampling: Blood samples were collected by piercing in the ventro-lateral side of the caudal peduncle with $5 \mathrm{~mL}$ disposable syringe and transferred to K3 EDTA tubes $(2.5 \mathrm{~mL})$ for hematological analyses and to gelled and vacuumed tubes $(5 \mathrm{~mL})$ for biochemical analyses. The tubes were closed and rinsed to prevent hemolysis and stored in cold until analysis (Das et al., 2004) (Table 1).

\section{Analyses}

Temperature and $\mathbf{p H}$ measurement: Temperature and $\mathrm{pH}$ of water was measured by $\mathrm{pH}$ meter. Water analyses were conducted at Tunceli Public Health Laboratories (Turkey).

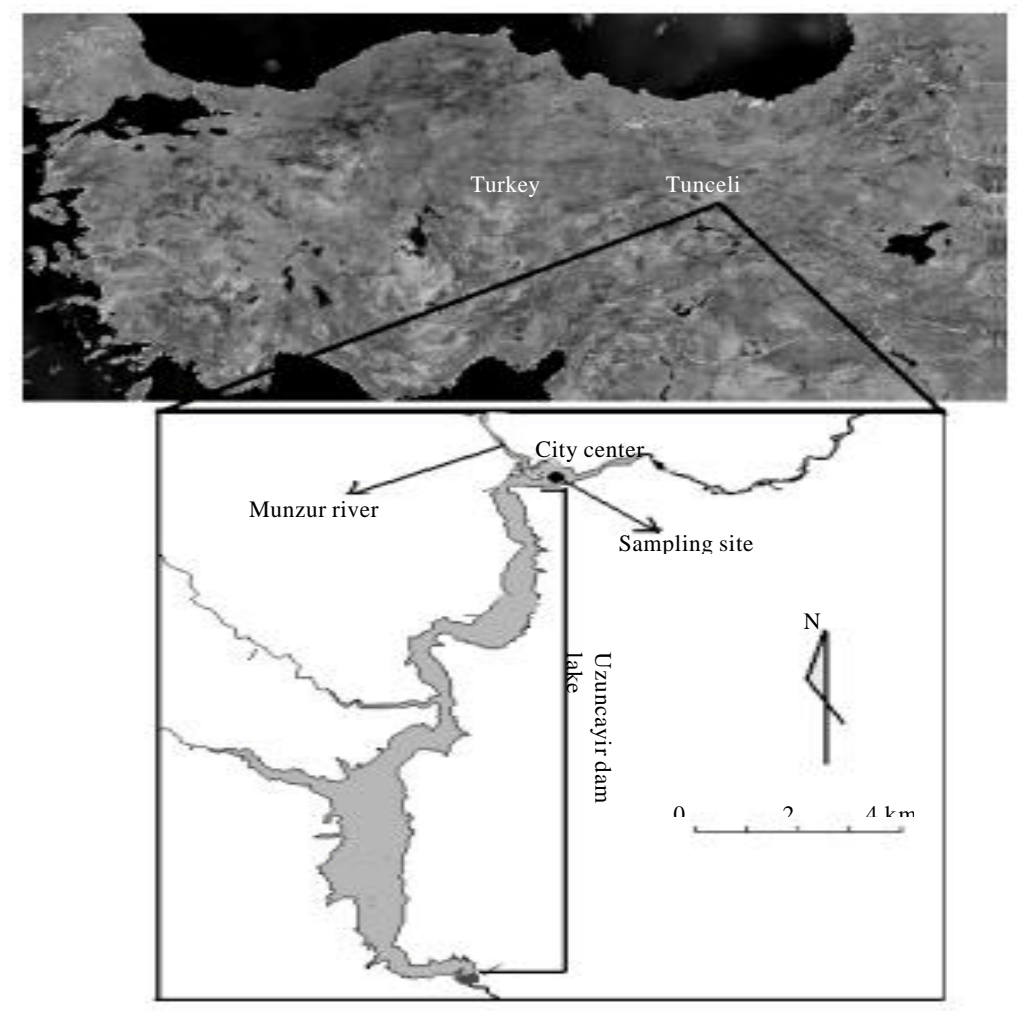

Fig. 1: Map of sampling site on Munzur river, Tunceli, Turkey 
Table 1: Some biochemical blood parameters of $C$. trutta caught from sampling site on Munzur river

\begin{tabular}{lrrr}
\hline Parameters & \multicolumn{1}{c}{ Means \pm SE } & Parameters & Means \pm SE \\
\hline RBC $\left(10^{12} \mathrm{~L}^{-1}\right)$ & $0.67 \pm 0.090$ & PCT (\%) & $0.061 \pm 0.01$ \\
HGB (g dL $)$ & $13.50 \pm 0.900$ & PDW (fL) & $19.77 \pm 1.710$ \\
HCT (\%) & $14.78 \pm 0.190$ & Fe (g dL $\left.{ }^{-1}\right)$ & $91.75 \pm 28.27$ \\
MCV (fL) & $218.40 \pm 4.290$ & $\mathrm{Cl}\left(\mathrm{mmol} \mathrm{L}^{-1}\right)$ & $92.00 \pm 4.020$ \\
MCH (pg) & $194.75 \pm 15.36$ & $\mathrm{P}\left(\mathrm{mg} \mathrm{dL}^{-1}\right)$ & $13.20 \pm 1.260$ \\
MCHC (g dL $\left.{ }^{-1}\right)$ & $108.52 \pm 1.090$ & $\mathrm{Ca}\left(\mathrm{mg} \mathrm{dL}^{-1}\right)$ & $11.65 \pm 0.740$ \\
PLT (10 $\left.0^{-1}\right)$ & $34.12 \pm 5.890$ & $\mathrm{~K}\left(\mathrm{mmol} \mathrm{L}^{-1}\right)$ & $1.30 \pm 0.210$ \\
MPV (fL) & $11.92 \pm 1.650$ & $\mathrm{Na}\left(\mathrm{mmol} \mathrm{L}^{-1}\right)$ & $132.5 \pm 3.9000$ \\
\hline
\end{tabular}

SE: Standart Error, $n=5$

Hematological analyses: Blood parameters ( $\mathrm{RBC}, \mathrm{HGB}$, $\mathrm{HCT}, \mathrm{MCV}, \mathrm{MCH}, \mathrm{MCHC}, \mathrm{PLT}, \mathrm{MPV}, \mathrm{PCT}$ and PDW) were determined by auto haematology analyzer (BC-5500).

Biochemical analyses: The blood sample was centrifuged at $4000 \mathrm{rpm}$ for $20 \mathrm{~min}$ (centrifuge; Universal $320 \mathrm{R}$ (Hettich Zentrifugen)) to separate the plasma and analyzed. $\mathrm{Na}, \mathrm{K}, \mathrm{Ca}, \mathrm{P}, \mathrm{Cl}$ and $\mathrm{Fe}$ were measured by kits (Lot numbers of kits; E485, E485, F133, F108, E485 and E389, respectively (purchased Thermo SCIENTIFIC)) using Konelab Prime 60I.

Statistical analysis: SPSS v13.0 statistical software was used for statistical analysis (SPSS Inc., Chicago, IL, USA). Data was statistically analyzed for means \pm standard error.

\section{RESULTS AND DISCUSSION}

In this study, haematological and biochemical parameters of Capoeta trutta in Munzur River were evaluated. The values of $\mathrm{RBC}, \mathrm{Hb}, \mathrm{Ht}, \mathrm{MCV}, \mathrm{MCH}$, MCHC, PLT, MPV, PCT and PDW from examined haematological parameters were found as $0.67 \pm 0.0910^{12}$ $\mathrm{L}^{-1}, 13.5 \pm 0.90 \mathrm{~g} \mathrm{dL}^{-1}, 14.78 \pm 0.19 \%, 218.40 \pm 4.29 \mathrm{fL}$, $194.75 \pm 15.36 \mathrm{pg}, 108.52 \pm 1.09 \mathrm{~g} \mathrm{dL}^{-1}, 34.12 \pm 5.8910^{9} \mathrm{~L}^{-1}$, $11.92 \pm 1.65 \mathrm{fL}, 0.061 \pm 0.01 \%$ and $19.77 \pm 1.71 \mathrm{fL}$, respectively. The values of $\mathrm{Fe}, \mathrm{Cl}, \mathrm{P}, \mathrm{Ca}, \mathrm{K}$ and $\mathrm{Na}$ from examined biochemical parameters were determined as $91.75 \pm 28.27 \mathrm{~g}$ $\mathrm{dL}^{-1}, 92.00 \pm 4.02 \mathrm{mmolL}^{-1}, 13.20 \pm 1.26 \mathrm{mg} \mathrm{dL}^{-1}, 11.65 \pm 0.74$ mmol L ${ }^{-1}, 1.30 \pm 0.21 \mathrm{mmol} \mathrm{L}^{-1}, 132.5 \pm 3.90 \mathrm{mg} \mathrm{dL}^{-1}$, respectively.

Since haematological parameters reflect the poor condition of fish more quickly than other commonly measured parameters and they respond quickly to changes in environmental conditions (Atkinson and Judd, 1978), they have been widely used for the description of healthy fish (Blaxhall, 1972) for monitoring stress responses (Soivio and Oikari, 1976) and for predicting systematic relationships and the physiological adaptations of animals. The increased RBCs count may be due to stimulation of erythropoietin by elevated demands for $\mathrm{O}_{2}$ or $\mathrm{CO}_{2}$ transport as a result of increased metabolic activity or destruction of gill membranes causing faulty gaseous exchange. The increase $\mathrm{Hb}$ content could be explained as a process where the body tries to replace the oxidized denatured $\mathrm{Hb}$ (Cyriac et al., 1989). The increase of HCT value and $\mathrm{MCHC}$ may be attributed to swelling of RBCs due to increased $\mathrm{CO}_{2}$ in blood, hypoxia or stressful procedures (Ellis, 1981; Nemesok and Boross, 1999).

Kori-Siakpere and Ubogu (2008) investigated sublethal haematological effects of zinc on the freshwater fish, Heteroclarias sp. (Osteichthyes: Clariidae). Haemotocrite, haemoglobine, $\mathrm{RBC}, \mathrm{MCHC}, \mathrm{MCH}, \mathrm{MCV}$ values were found in the range of $24.8-38.4 \%, 8.34-15.38$ $\mathrm{g} \mathrm{dL}^{-1}, 1.24-1.6310^{6} \mathrm{~mm}^{-3}, 34.63-35.47 \%, 68.30-97.28 \mathrm{pg}$, 204.85-240.18 $\mu \mathrm{g}$ in blood of fishes, respectively. Fantin et al. (1988) investigated effects of acute experimental pollution by lead on some haematological parameters in Carassius carassius (L.) Var. auratus. The following differences were observed between control and treated samples; the number of RBC was decreased after $48 \mathrm{~h}$ of treatment; $\mathrm{Ht}, \mathrm{Hb}$ percentage and $\mathrm{MCHC}$ were also decreased. Maximum and minimum $\mathrm{RBC} \times 10^{3} \mathrm{mrr}^{-3}$, Thrombocytes $\times 10^{3} \mathrm{mn}^{-3}, \mathrm{HCT}(\%), \operatorname{HGB}(\%), \operatorname{MCV}\left(\mu \mathrm{m}^{3}\right)$ ,MCHC (pg) values were found to be 1634.00-1488.00, 70.18-63.21, 26.7-24.3, 11.9-9.9, 168.71-161.08, 43.65-40.5, 70.9-69.6. in blood of fishes, respectively. Kandemir et al. (2010) determinated heavy metal levels, oxidative status, biochemical and hematological parameters in Cyprinus carpio (L., 1978) from Bafra (Samsun) fish lakes. They show that heavy metals levels may increase in fishes living in Bafra Lakes because of both domestic waste water and agricultural activities. Atamanalp and Yanik (2003) investigated alterations in hematological parameters of rainbow trout (Oncorhynchus mykiss) exposed to mancozeb. It was determined that the use of the pesticide caused a slight increase in $\mathrm{RBC}$ numbers and a decrease in $\mathrm{Hb}, \mathrm{MCH}, \mathrm{MCHC}, \mathrm{PCV}, \mathrm{MCV}$ and $\mathrm{WBC}$ levels. Significant decreases in $\mathrm{Hb}$ content and in $\mathrm{MCH}$ were observed during exposure to the pesticide.

In this study, the values of $\mathrm{RBC}, \mathrm{Hb}, \mathrm{Ht}, \mathrm{MCV}, \mathrm{MCH}$, MCHC, PLT, MPV, PCT, PDW from examined haemetological parameters were found as $0.67 \pm 0.0910^{12}$ $\mathrm{L}^{-1}, 13.5 \pm 0.90 \mathrm{~g} \mathrm{dL}^{-1}, 1478 \pm 0.19 \%, 218.40 \pm 4.29 \mathrm{fL}$, $194.75 \pm 15.36 \mathrm{pg}, 108.52 \pm 1.09 \mathrm{~g} \mathrm{dL}^{-1}, 34.12 \pm 5.8910^{9} \mathrm{~L}^{-1}$, $11.92 \pm 1.65 \mathrm{fL}, 0.061 \pm 0.01 \%$ and $19.77 \pm 1.71 \mathrm{fL}$, respectively.

Atamanalp et al. (2002) investigated that the effects of cypermethrin (a synthetic pyrethroid) on some biochemical parameters ( $\mathrm{Ca}, \mathrm{P}, \mathrm{Na}$ and $\mathrm{TP}$ ) of rainbow trout. After 15 days exposure, $\mathrm{Ca}$ and $\mathrm{P}$ decreased while $\mathrm{TP}$ and $\mathrm{Na}$ took various values depending on the doses of synthetic pyrethroid. Zeynali et al. (2009) determinated the $\mathrm{Cu}, \mathrm{Zn}$ and $\mathrm{Fe}$ levels in edible muscle of three 
commercial fish species from Iranian coastal waters of the Caspian Sea. Mean concentrations of $\mathrm{Fe}$ in muscles of mullet, sefid and common carp were 81.11, 73.59 and $94.78 \mathrm{mg} \mathrm{kg}^{-1}$, respectively. Three species fish samples collected from Bangladesh and $\mathrm{Ca}, \mathrm{Na}, \mathrm{Mg}$ and $\mathrm{Fe}$ concentrations were found in the range of 3650-6570, $2950-4580,2060-2560$ and $71-186 \mu \mathrm{g} \mathrm{g}^{-1}$ in the muscle tissue of fishes, respectively (Begum et al., 2005). Mendil et al. (2010) investigated the trace metals in different fish species and sediments from the River Yesilirmak in Tokat, Turkey.

Luczynska et al. (2009) analyzed muscle of four fish speices such as, roach, bream, perch and pike and they found Fe concentrations $1.877,1.881,1.083,0.987 \mathrm{mg} \mathrm{kg}^{-1}$ wet weight, $\mathrm{Na}$ concentrations 51.3, 55.1, 61.4, $62.0 \mathrm{mg} \mathrm{kg}^{-1}$ wet weight, $\mathrm{K}$ concentrations $437.1,421.2$, $415.7,425 \mathrm{mg} \mathrm{kg}^{-1}$ wet weight, $\mathrm{Mg}$ concentrations 22.8 , $19.4,19.8,22.8 \mathrm{mg} \mathrm{kg}^{-1}$ wet weight, Ca concentrations $17.2,14.0,13.1,11.0 \mathrm{mg} \mathrm{kg}^{-1}$ wet weight, $\mathrm{P}$ concentrations $234.1,231.8,233.4,238.0 \mathrm{mg} \mathrm{kg}^{-1}$ wet weight, respectively. The concentrations of macro elements were noted in the following order: $\mathrm{K}>\mathrm{P}>\mathrm{Na}>\mathrm{Mg}>\mathrm{Ca}$ in different fish muscle tissues samples. Roach and bream had more $\mathrm{Fe}$ than perch and pike (Luczynska et al., 2009).

Fantin et al. (1988) assayed $\mathrm{Na}^{+}, \mathrm{K}^{+}, \mathrm{Cl}^{-}, \mathrm{Ca}^{++}$in specimens of Carassiu carassius (L.) var. auratus submitted to sublethal acute exposure to lead ( 5 ppm., 24 and $48 \mathrm{~h}$ ). $\mathrm{K}, \mathrm{Na}, \mathrm{Cl}$ and Ca concentration ( $\mathrm{meg} \mathrm{mL}^{-1}$ ) inreference site were determined as 7.04, 131.5, 106.2, 3.57, respectively but in polluted site $\mathrm{K}, \mathrm{Na}, \mathrm{Cl}$ and $\mathrm{Ca}$

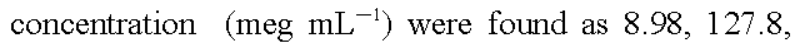
$100.9,3.61$, after $24 \mathrm{~h}, 7.81,132.5,109.1,2.9$, after $48 \mathrm{~h}$ (Fantin et al., 1988).

As a result of the study, the values of $\mathrm{Fe}, \mathrm{Cl}, \mathrm{P}, \mathrm{Ca}, \mathrm{K}$, $\mathrm{Na}$ from examined biochemical parameters were determined as $91.75 \pm 28.27 \mathrm{~g} \mathrm{dL}^{-1}, 92.00 \pm 4.02 \mathrm{nmol} \mathrm{L}^{-1}$, $13.20 \pm 1.26 \mathrm{mg} \mathrm{dL}^{-1}, 11.65 \pm 0.74 \mathrm{mmol} \mathrm{L}^{-1}, 1.30 \pm 0.21 \mathrm{mmol}$ $\mathrm{L}^{-1}, 132.5 \pm 3.90 \mathrm{mg} \mathrm{dL}-1$, respectively.

\section{CONCLUSION}

To the knowledge this is the first report show in that haemetological and biochemical parameters of Capoeta trutta from Munzur River. Results of these investigations suggest that the intensity of pollution is responsible for altering the haematology and biochemistry of Capoeta trutta in Munzur River. Haemotological and biochemical parameters of fish should be checked regularly for food safety and environmental pollution.

\section{REFERENCES}

Altun, T. and D. Danabas, 2006. Effects of short and long exposure to the anesthetic 2-phenoxyethanol mixed with ethyl alcohol on common carp (Cyprinus carpio L., 1758) fingerlings. Israeli J. Aquacult. Bamidgeh, 58: 178-182.

Atamanalp, M. and T. Yanik, 2003. Alterations in hematological parameters of rainbow trout (Oncorhynchus mykiss) exposed to mancozeb. Turk. J. Vet. Anim. Sci., 27: 1213-1217.

Atamanalp, M., M.S. Keles, H.I. Haliloglu and M.S. Aras, 2002. The effects of cypermethrin (a synthetic pyrethroid) on some biochemical parameters ( $\mathrm{Ca}, \mathrm{P}$, $\mathrm{Na}$ and TP) of rainbow trout (Oncorhynchus mykiss). Turk. J. Vet. Anim. Sci., 26: 1157-1160.

Atkinson, J. and F.W. Judd, 1978. Comparative haematology of Lepomis microlophus and Cichlosoma cyanogutatum. Copeia, 12: 230-237.

Begum, A., M.N. Amin, K. Satoshi and O. Kiyohisa, 2005. Selected elemental composition of the muscle tissue of three species of fish, Tilapia nilotica, Cirrhina mrigala and Clarius batrachus, from the fresh water dhanmondi lake in Bangladesh. Food Chem., 93: 439-443.

Blaxhall, P.C., 1972. The haematological assessment of the health of freshwater fish. Review of selected literature. J. Fish Biol., 4: 593-604.

Borkovic, S.S., S.Z. Pavloviæ, T.B. Kovacevic, A.S. Stajn, V.M. Petroviæ and Z.S. Saieie, 2008. Antioxidant defence enzyme activities in hepatopancreas, gills and muscle of Spiny cheek crayfish (Orconectes limosus) from the River Danube. Comp. Biochem. Physiol. Part C Toxicol. Pharmacol., 147: 122-128.

Campbell, T.W., 2004. Hematology of lower vertebrates. Proceedings of the 55th Annual Meeting of the American College of Veterinary Pathologists (ACVPC) and 39th Annual Meeting of the American Society of Clinical Pathology (ASVCP), Nov. 13, International Veterinary Pathologists and American Society for Veterinary Clinical Pathology, Middleton WI, USA, 1-5.

Casillas, E. and L.S. Smith, 1977. Effect of stress on blood coagulation and haematology of rainbow trout (Salmo gairdneri). J. Fish Biol., 10: 481-491.

Cyriac, P.J., A. Antony and P.K.N. Nambison, 1989. Haemoglobin and haematocrit values in the fish Oreochromis mossambicus (peters) after short term exposure to copper and lead. Bull. Environ. Contam. Toxicol., 43: 315-320. 
Das, P.C., S. Ayyappan, J.K. Jena and B.K. Das, 2004. Effect of sub-lethal nitrite on selected haematological parameters in fingerling Catla catla (Hamilton). Aquac. Res., 35: 874-880.

Depledge, M.H., A. Aagaard and R. Gyorkos, 1995. Assessment of trace metal toxicity using molecular, physiological and behavioral biomarkers. Mar. Pollut. Bull., 31: 19-27.

Duthie, G.G. and L. Tort, 1985. Effect of dorsal aortic cannulation on the respiration and haematology of the mediterranean dog-fish Scyliorhinus canicula. Comp. Biochem. Physiol., 81: 879-883.

Ellis, A.E., 1981. Stress and the Modulation of Defence Mechanisms in Fish. In: Stress and Fish, Pickering, A.D. (Ed.). Academic Press London, London, pp: 147-170.

Fantin, A.M.B., P. Trevisan, A. Pederzoli and M. Bergomi, 1988. Effects of acute experimental pollution by lead on some haematological parameters in Carassius carassius (L.) var. auratus. Ital. J. Zool., 55: 251-255.

Hesser, E.F., 1960. Methods for routine on fish hematology. Prog. Fish Culturist, 22: 164-171.

Kandemir, S., M.I. Dogru, I. Orun, A. Dogru and L. Altas et al., 2010. Determination of heavy metal levels, oxidative status, biochemical and hematological parameters in Cyprinus carpio L., 1758 from Bafra (Samsun) fish lakes. J. Anim. Vet. Adv., 9: 617-622.

Kori-Siakpere, O. and E.O. Ubogu, 2008. Sublethal haematological effects of zinc on the freshwater fish, Heteroclarias sp. (Osteichthyes: Clariidae). Afr. J. Biotechnol., 7: 2068-2073.

Larsson, A., C. Haux and M. Sjobeck, 1985. Fish physiology and metal pollution result and experience from laboratory and field studies. Ecotoxicol. Environ. Saf., 9: 250-281.

Luczynska, J., E. Tonska and M.J. Luczynski, 2009. Essential mineral components in the muscles of six freshwater fish from the Mazurian Great Lakes (North-Eastern Poland). Arch. Pol. Fish., 17: 171-178.
Mendil, D., O.F. Unal, M. Tuzen and M. Soylak, 2010. Determination of trace metals in different fish species and sediments from the River Yepilýrmak in Tokat, Turkey. Food Chem. Toxicol., 48: 1383-1392.

Milligan, C.L. and C.M. Wood, 1982. Disturbances in hematology, fluid volume distribution and circulatory function associated with low environmental $\mathrm{pH}$ in the rainbow trout (Salmo gairdneri). J. Exp. Biol., 99: 397-415.

Nemesok, J. and L. Boross, 1999. Comparative studies on the sensitivity of different fish species to metal pollution. Hoto Biol. Hung, 33: 27-27.

Przybyl, A. and A. Koligot, 1997a. The role of mineral components in the animal nutrition II. MicroelementsPrz. Ryb., 3: 38-42.

Przybyl, A. and A. Koligot, 1997b. The role of mineral components in the animal nutrition I. MacroelementsPrz. Ryb., 2: 48-52.

Sardella, B.A., V. Matey, J. Cooper, R.J. Gonzalez and C.J. Brauner, 2004. Physiological, biochemical and morphological indicators of osmoregulatory stress in California mozambique tilapia (Oreochromis mossambicus $\mathrm{x}$ O. urolepis hornorum) exposed to hypersaline water. J. Exp. Biol., 207: 1399-1413.

Soivio, A. and A. Oikari, 1976. Haematological effects of stress on a teleost Esox lucius L. J. Fish Biol., 8: $397-411$.

Van Vuren, J.H.J., 1986. The effects of toxicants on the haematology of Labeo umbratus (Teleostei: Cyprinidae). Comp. Biochem. Physiol., 93: 155-159.

Walker, C.H., S.P. Hopkin, R.M. Sibly and D.B. Peakall, 2001. Principles of Ecotoxicology. 2nd Edn., Taylor and Francis Inc., New York, London.

Zeynali, F., T. Hossein, A.R. Siamak, M. Saeed, A. Fallah and M. Rahnama, 2009. Determination of copper, zinc and iron levels in edible muscle of three commercial fish species from Iranian coastal waters of the Caspian Sea. J. Anim. Vet. Adv., 8: 1285-1288. 